\title{
Comparison of the Affinity Chromatography and the Ion Exchange Chromatography in the Isolation of Bovine Immunoglobin G
}

\author{
Mrigendra Rajput1*, Shimaa M. G. Mansour², Lyle J. Braun³, Mahmoud Darweesh³, \\ Neelu Thakur ${ }^{3}$, Christopher C. L. Chase ${ }^{3}$ \\ ${ }^{1}$ Medgene Labs, Brookings, SD, USA \\ ${ }^{2}$ Department of Virology, Faculty of Veterinary Medicine, Zagazig University, Zagazig, Egypt \\ ${ }^{3}$ Department of Veterinary and Biomedical Sciences, South Dakota State University, Brookings, SD, USA \\ Email: ${ }^{*}$ mrigendra.rajput@jacks.sdstate.edu
}

Received 28 June 2014; revised 1 August 2014; accepted 10 September 2014

Copyright (C) 2014 by authors and OALib.

This work is licensed under the Creative Commons Attribution International License (CC BY).

http://creativecommons.org/licenses/by/4.0/

(c) (i) Open Access

\section{Abstract}

The purified Immunoglobulin G (IgG) is effectively used in passive immunization. There are various methods to isolate the IgG from serum, with its own advantages and disadvantages. In the current study, a comparative efficacy of the affinity chromatography using Protein A-Sepharose and ion exchange chromatography using DEAE Sephadex A50 was done with regard to yield and purity of IgG. Both methods were found equally effective in isolation of pure IgG with similar recovery, indicating that researcher can use either method to purify IgG depending on available resources.

\section{Keywords}

Affinity Chromatography, Ion Exchange Chromatography, Bovine Immunoglobin G

Subject Areas: Agricultural Science, Microbiology, Veterinary Medicine

\section{Introduction}

Immunoglobulins are protein molecules that are produced by plasma cells in response to an immunogen. In 1890, von Behring and Kitasato reported the existence of antibody as an agent in the blood that could neutralize diphtheria toxin [1]. In the following year that agent was named as "Antikörper", or antibodies. The immunoglobulin molecule consists of two heavy and two light chains. The light chain may have either a $\kappa$ (kappa) or a $\lambda$ (lambda) chain. There are five constant domain/chains. On the basis of constant domains, immunologlobulins can be di-

\footnotetext{
${ }^{*}$ Corresponding author.
}

How to cite this paper: Rajput, M., Mansour, S.M.G., Braun, L.J., Darweesh, M., Thakur, N. and Chase, C.C.L. (2014) Comparison of the Affinity Chromatography and the Ion Exchange Chromatography in the Isolation of Bovine Immunoglobin G. Open Access Library Journal, 1: e960. http://dx.doi.org/10.4236/oalib.1100889 
vided into 5 isotypes, IgM, IgG, IgA, IgD, and IgE [2]. All isotopes are monomers except IgM and IgA. IgM is pentamer while IgA is dimer. IgG is the most versatile and major immunoglobulin in the blood, colostrum and extracellular fluid in human [3]. IgG plays an important role in controlling the disease. It controls invading pathogens via opsonization. The opsonization facilitates phagocytosis of invading organism by immune cells and helps in antibody dependent cell mediated cytotoxicity (ADCC). It activates the classical pathway of complement system and can neutralize the bacteria, virus or toxins. It also plays an important role in intracellular antibody mediated proteolysis [4]. The IgG is frequently used in passive immunization. The attainment of passive immunity in newborn calves occurs through the oral consumption and subsequent absorption of immunoglobulin soon after birth [5]. Low blood immunoglobulin concentrations are directly related to calf morbidity and mortality [5]. To increase the immunity of calves, purified IgG is given either in form of oral or parental administration. In the current study, we compare the two methods to isolate purified IgG from bovine serum that can be used in passive immunization.

\section{Materials and Methods}

\subsection{Animals}

Holstein Friesian cows housed at the Dairy Farm, South Dakota State University, Brookings, SD, U.S.A. were used in this study. All animals were healthy and vaccinated with "ViraShield" vaccine (Novartis Animal Health US, Inc), contained Bovine Rhinotracheitis-Virus Diarrhea-Parainfluenza 3-Respiratory Syncytial Virus Vaccine, Killed Virus-Campylobacter Fetus-Leptospira Canicola-Grippotyphosa-Hardjo-Icterohaemorrhagiae-Pomona Bacterin. Animal handling and blood collection methods were approved by the SDSU Institutional Animal Care and Use Committee.

\subsection{Isolation of Immunoglobulin}

Eighty (80) ml blood was collected from three cows in serum collecting vacuumed tubes. To separate serum, tubes were centrifuged at $2000 \mathrm{rpm}$ for 30 minutes at $4^{\circ} \mathrm{C}$. Following centrifugation, $8 \mathrm{ml}$ serum was aspirated and sodium azide was added as a preservative to achieve final concentration as $0.1 \%$. The $8 \mathrm{ml}$ serum from each cow was divided in to two tubes with $4 \mathrm{ml}$ each (one for affinity chromatography and other for ion-exchange chromatography). A $45 \%$ ammonium sulfate solution was added to each tube in 2:3 ration (v/v) to precipitate the immunoglobulin, followed by centrifugation at $10,000 \mathrm{rpm}$ for 20 minutes at $4^{\circ} \mathrm{C}$. The immunoglobin pellet was dissolved in PBS (1/3 volume of original serum). This Ig solution was dialyzed using 75/100 Kd dialyzing tube (Sigma-Aldrich, St. Louis, MO, USA). The dialysis was done with PBS at $4^{\circ} \mathrm{C}$ for 24 hrs by replacing PBS every 6 hrs with continuous stirring.

\subsection{Isolation of IgG Using Protein A-Sepharose}

Total two grams of Protein A-Sepharose (Sigma-Aldrich, St. Louis, MO, USA) was allowed to come to equilibrium in $10 \mathrm{mM}$ phosphate buffer saline $(\mathrm{pH}$ : 8) containing $0.1 \%$ sodium azide. The chromatography column $(15 \mathrm{~cm} \times 0.5 \mathrm{~cm})$ was packed with equilibrated Protein A-Sepharose up to 2/3 of the length. The column was activated using $10 \mathrm{ml}$ acid buffer (0.5 M glycine with HCL, pH: 2.8). Following activation, the column was neutralized using $200 \mathrm{ml} 0.1 \mathrm{M}$ phosphate buffer (pH: 8). The $1 \mathrm{ml}$ dialyzed serum was applied over the column and elude was discarded. The column was washed 3 times with $0.1 \mathrm{M}$ phosphate buffer (pH: 8). The IgG was eluted using $10 \mathrm{ml}, 0.1 \mathrm{M}$ sodium citrate (pH: 4) containing $0.1 \%$ sodium azide. The obtained elute was measured for protein concentration by Nanodrop, ND-1000 spectrophotometer (Thermo scientific, Wilmington, DE, USA) followed by confirmation of IgG using SDS PAGE.

\subsection{Isolation of IgG Using DEAE Sephadex A50}

The DEAE Sephadex A50 (GE Healthcare Bio-Sciences,Uppsala, Sweden) was swollen in $0.1 \mathrm{M}$ tris buffer (pH: 8.3). The chromatography column $(15 \mathrm{~cm} \times 0.5 \mathrm{~cm})$ was filled by DEAE Sephadex A50 up to $2 / 3$ of the length. The $1 \mathrm{ml}$ dialyzed serum was applied over the column and elute was discarded. The column was washed with $0.1 \mathrm{M}$ tris buffer (pH: 8.3). The IgG was eluted using $10 \mathrm{ml}, 0.1 \mathrm{M}$ tris buffer containing $0.22 \mathrm{M}$ sodium chloride (pH: 8.3). The obtained elude was measured for protein concentration by Nanodrop, ND-1000 spectrophotometer (Thermo scientific, Wilmington, DE, USA) followed by identification of IgG using SDS PAGE. 


\subsection{Sodium Dodecyl Sulfate Polyacrylamide Gel Electrophoresis}

The sodium dodecyl sulfate polyacrylamide gel electrophoresis (SDS-PAGE) was performed with and without protein denaturation. For protein denaturation, samples were mixed with loading dye containing SDS and beta mercaptoethanol and samples were heated at $100^{\circ} \mathrm{C}$ for 10 minutes. For non-denaturation, samples were mixed in loading dye lacking beta mercaptoethanol and SDS and samples were not heated at $100^{\circ} \mathrm{C}$. To separate protein, samples were run with $10 \%$ resolving gel. The protein bands were visualized using the coomassie blue staining.

\section{Results}

The IgG was isolated in pure form by the both affinity chromatography using Protein A-Sepharose as well as anion exchange chromatography using DEAE Sephadex A50. In both methods, the non-denatured IgG was observed at $150 \mathrm{kD}$ (Figure 1(a) and Figure 1(b)), while the denatured gel revealed two bands with molecular size of $50 \mathrm{kD}$ (heavy chain) and $25 \mathrm{kD}$ (light chain) (Figure 1(c) and Figure 1(d)).

The yield of IgG by affinity chromatography and anion exchange chromatography revealed as $17.13 \pm 2.08$ $\mathrm{mg} / \mathrm{ml}$ and $17.00 \pm 1.60 \mathrm{mg} / \mathrm{ml}$, respectively, which were significantly similar to each other $(\mathrm{p}<0.05)$ (Table 1).

These results indicated that the both affinity chromatography and ion exchange chromatography are equally efficient in isolating the IgG from serum samples.

\section{Discussion}

The current study revealed that ion exchange chromatography using DEAE Sephadex A50 and affinity chromatography using Protein A-Sepharose are equally effective in isolating the IgG. The both technique isolated the

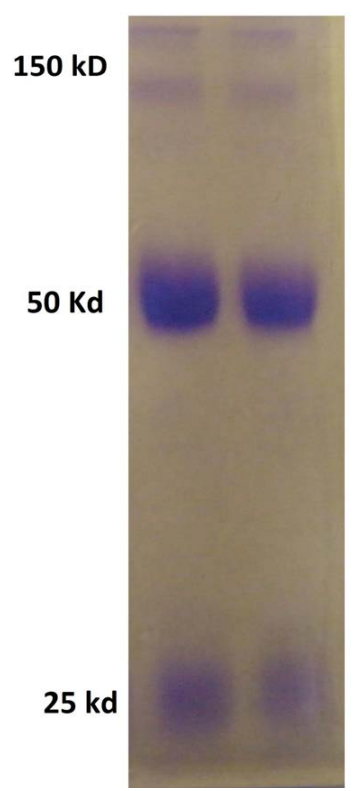

(a)

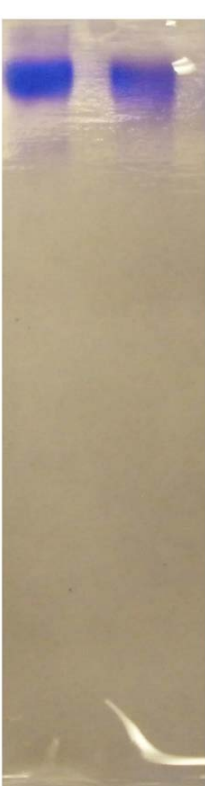

(c)

(d) 
Table 1. Concentration of IgG using affinity chromatography and exchange chromatography. The immunoglobulin G (IgG) was isolated from bovine serum through affinity chromatography or ion exchange chromatography. The concentration of isolated IgG was measured through Nanodrop, ND-1000 spectrophotometer.

\begin{tabular}{ccc}
\hline Sample & $\begin{array}{c}\text { The concentration of the IgG using Protein } \\
\text { A-Sepharose/ affinity chromatography } \mathbf{( m g / m l )}\end{array}$ & $\begin{array}{c}\text { The concentration of IgG using DEAE Sephadex } \\
\text { A50/ion exchange chromatography (mg/ml) }\end{array}$ \\
\hline Sample 1 & 17.8 & 17.5 \\
Sample 2 & 14.8 & 15.2 \\
Sample 3 & 18.8 & 18.3 \\
Average & $17.13 \pm 2.08$ & $17.00 \pm 1.60$ \\
\hline
\end{tabular}

IgG in pure form with similar concentration. The recovery of IgG from $1 \mathrm{ml}$ dialyzed serum protein using affinity chromatography and anion exchange chromatography was $17.13 \pm 2.08 \mathrm{mg} / \mathrm{ml}$ and $17.00 \pm 1.60 \mathrm{mg} / \mathrm{ml}$, respectively. The actual concentration of serum IgG may be different, as some of IgG may be lost during isolation process.

The IgG is widely utilized in the immunological and dietary supplementation [6]. The study showed that oral consumption of bovine IgG reduced the viral gastroenteritis [7], along with dietary supplements, purified IgG also used in passive immunization [8] and various diagnostic assays [9]. There are various methods have been standardized to isolate the IgG, the choice of procedure generally depends upon intended used of IgG and recourses available. The current study was conducted to compare the two methods that are widely used in the laboratories to isolate the substances. It will be worth interesting to compare other methods including HPLC (High-performance liquid chromatography) to isolate the IgG in different species. The comparative studies will be useful for future reference through which researcher can choose the best method for his/her work.

\section{Conclusion}

The current study indicated that affinity chromatography and ion-exchange chromatography using Protein ASepharose and the DEAE Sephadex A50 respectively have same efficiency to isolate the immunoglobulin G, in terms of purity and yield.

\section{Acknowledgements}

Authors would like to thanks Dairy Research and Training Facility, South Dakota State University, Brookings, USA for providing animals for research and Functional Genomics Core Facility, South Dakota State University, Brookings, USA for providing Nanodrop facility.

\section{References}

[1] Haas, L.F. (2001) Emil Adolph von Behring (1854-1917) and Shibasaburo Kitasato (1852-1931). Journal of Neurology, Neurosurgery and Psychiatry, 71, 62. http://dx.doi.org/10.1136/jnnp.71.1.62

[2] Schroeder Jr., H.W. and Cavacini, L. (2010) Structure and Function of Immunoglobulins. The Journal of Allergy and Clinical Immunology, 125, 41-52. http://dx.doi.org/10.1016/j.jaci.2009.09.046

[3] Hvatum, M., Scott, H. and Brandtzaeg, P. (1992) Serum IgG Subclass Antibodies to a Variety of Food Antigens in Patients with Coeliac Disease. Gut, 33, 632-638. http://dx.doi.org/10.1136/gut.33.5.632

[4] Mallery, D.L., McEwan, W.A., Bidgood, S.R., Towers, G.J., Johnson, C.M. and James, L.C. (2010) Antibodies Mediate Intracellular Immunity through Tripartite Motif-Containing 21 (TRIM21). Proceedings of the National Academy of Sciences of the United States of America, 107, 19985-19990. http://dx.doi.org/10.1073/pnas.1014074107

[5] Bush, L.J. and Staley, T.E. (1980) Absorption of Colostral Immunoglobulins in Newborn Calves. Journal of Dairy Science, 63, 672-680. http://dx.doi.org/10.3168/jds.S0022-0302(80)82989-4

[6] Gapper, L.W., Copestake, D.E., Otter, D.E. and Indyk, H.E. (2007) Analysis of Bovine Immunoglobulin G in Milk, Colostrum and Dietary Supplements: A Review. Analytical and Bioanalytical Chemistry, 389, 93-109. http://dx.doi.org/10.1007/s00216-007-1391-z

[7] Guarino, A., Canani, R.B., Russo, S., Albano, F., Canani, M.B., Ruggeri, F.M., Donelli, G. and Rubino, A. (1994) Oral Immunoglobulins for Treatment of Acute Rotaviral Gastroenteritis. Pediatrics, 93, 12-16. 
[8] Kiraly, J., Vareckova, E., Mucha, V. and Kostolansky, F. (2011) Evaluation of Anti-Influenza Efficiency of Polyclonal IgG Antibodies Specific to the Ectodomain of M2 Protein of Influenza A Virus by Passive Immunization of Mice. Acta Virologica, 55, 261-265. http://dx.doi.org/10.4149/av_2011_03_261

[9] Pare, J., Hietala, S.K. and Thurmond, M.C. (1995) An Enzyme-Linked Immunosorbent Assay (ELISA) for Serological Diagnosis of Neospora sp. Infection in Cattle. Journal of Veterinary Diagnostic Investigation, 7, 352-359. http://dx.doi.org/10.1177/104063879500700310 